\title{
Competition proceedings and fundamental rights: another piece of the puzzle
}

\section{Maria Luisa Stasi}

Published online: 12 April 2013

(C) ERA 2013

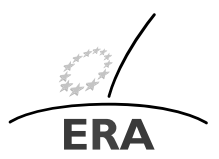

EUROPÄ̈ISCHE RECHTSAKADEMIE ACADEMY OF EUROPEAN LAW ACADEMIE DE DROIT EUROPEEN ACCADEMIA DI DIRITTO EUROPEO TRIER - TREVES - TREVIRI

Keywords Commission's powers · Inspection decisions · Fundamental rights of the parties

As provided in Article 51, par. 1 of the EU Charter of Fundamental Rights, ${ }^{1}$ the European Commission (hereinafter the "Commission"), alongside the other institutions, bodies, offices and agencies of the Union, shall "respect the rights, observe the principles and promote the application thereof in accordance with (its) respective powers and respecting the limits of the powers of the Union as conferred on it in the Treaties".

With regard in particular to the Commission's powers of implementation of the Treaty rules on competition law, recital 37 of Regulation No. $1 / 2003^{2}$ declares that the rules contained therein respect the fundamental rights and observe the principles recognised by the above-mentioned Charter and that, accordingly, the Regulation itself should be interpreted and applied with respect to those rights and principles.

Notwithstanding the above, in recent times the antitrust system in force within the European Union has been widely criticised by legal practitioners and academics.

\footnotetext{
${ }^{1}$ Charter of Fundamental Rights of the European Union of 7 December 2000, OJ C 364, 18.12.2000, pp. 1-22.

${ }^{2}$ Council Regulation (EC) No. 1/2003 of 16 December 2002 on the implementation of the rules on competition laid down in Articles 81 and 82 of the Treaty, OJ L 1, 4.1.2004, pp. 1-25.
}

M.L. Stasi, Course Director $(\bowtie)$

Business law section, ERA Academy of European Law, Metzer Allee 4, 54295 Trier, Germany

e-mail: mstasi@era.int 
Following the hints conveyed by some recent European case law, ${ }^{3}$ a number of aspects concerning the procedure for the application of Articles 101 and 102 TFEU by the Commission and the standard of judicial review by the European Courts of its decisions have been accused of not allowing undertakings to defend their rights effectively. ${ }^{4}$

Perhaps incited by similar criticisms, and in order to increase understanding of the investigation process and ensure a high degree of transparency and predictability, the Commission published, in October 2011, its "Notice on Best Practices" of proceedings concerning Articles 101 and 102 TFEU. ${ }^{5}$ Less than one year later, and beating the same path towards greater transparency, it published its Internal Manual of Procedures. ${ }^{6}$ In spite of those steps, the Commission's procedure in antitrust cases continues to face a number of critics, and the European Courts are often called upon to rule on the lawfulness of the Commission's behaviour during proceedings for the implementation of competition rules. ${ }^{7}$

One of the most invasive investigative powers held by the Commission is to conduct the necessary inspections at the premises of undertakings or association of undertakings, ${ }^{8}$ so it is not surprising that in a number of cases the European Courts had to rule on the content and limits of this power. ${ }^{9}$

\footnotetext{
${ }^{3}$ Reference is made, in particular, to the following cases, from which it is possible to draw the view of the Court of Justice of the European Union concerning the standard of review of the Commission decisions and its compliance with the EU Charter: case C-389/10 P-KME Germany e.a. v Commission, (not yet reported); case C-272/09 P-KME Germany e.a. v Commission, (not yet reported); case C-386/10 PChalkor $v$ Commission, (not yet reported). In the analysis of the issue, what the European Court of Human Rights has established in the Menarini case should also be considered: case no. 43509/08, A. Menarini Diagnostics S.R.L. v. Italy, judgment of 27 September 2011.

${ }^{4}$ See, among others, Editorial Comments [3], p. 1405, 1411; Bronckers, Vallery [2], 535-570; Bombois [1].

${ }^{5}$ Commission Notice on Best Practices for the conduct of proceedings concerning Articles 101 and 102 TFEU, OJ C 308, 20.10.2011, pp. 6-32.

${ }^{6}$ Commission Antitrust Manual of Procedures, Internal DG Competition working documents on procedures for the application of Articles 101 and 102 TFEU, March 2012.

${ }^{7}$ See, among others, Case C-89/11 P, E.ON Energie v Commission, 22 December 2012 (not yet reported); Joined cases C-628/10 P and C-14/11 P, Alliance One International Inc. and Standard Commercial Tobacco Co. Inc. v European Commission and European Commission v Alliance One International Inc. and Others, 19 July 2012 (not yet reported); Case C-90/09, General Química and Others v Commission, 20 January 2011, [2011] ECR I-00001; Case C-521/09 P, Elf Aquitaine v Commission, 29 September 2011, (not yet reported); Joined cases C-109/10 P and C-110/10 P, Solvay v Commission, 25 October 2011, (not yet reported); Case T-133/07, Mitsubishi Electric Corp. v Commission, 12 July 2011, (not yet reported) under appeal in Case C-489/11 P; Case T-132/07 Fuji Electric v Commission, 12 July 2011 (not yet reported).

${ }^{8}$ See Article 20 of Regulation No 1/2003, cit.

${ }^{9}$ See, among others, Case C-94/00, Roquette Frères SA v Directeur général de la concurrence, 22 October 2002, [2002] ECR I-9011; Case T-339/04, France Télécom SA v European Commission, 8 March 2007, [2007] ECR II-521; Joined cases T-125/03 and T-253/03, Akzo Nobel Chemicals Ltd and Akros Chemicals Ltd $v$ European Commission, 17 September 2007, [2007] ECR II-3523; Case C-550/07 P, Akzo Nobel Chemicals Ltd and Akros Chemicals Ltd v European Commission, 14 September 2010, [2010] ECR I8301.
} 
This key topic was the subject of the ERA seminar held on 13-14 September 2012 in Barcelona. ${ }^{10}$ During the conference, a number of high-level speakers from different EU countries analysed the regulatory framework of the Commission's powers, the level of protection of private parties' rights before the EU Courts in Luxembourg and the European Court of Human Rights in Strasburg, the role of national judges during inspections as well as the exportation of standards for the protection of companies' rights in cases of re-allocations.

One of the most lively discussions concerned the Commission's dos and don'ts during inspections. A lawyer in private practice and a Commission representative shared the floor enriching the audience with their different perspectives and most recent experiences.

In November last year, the General Court, with its twin judgments on cases T$140 / 09,{ }^{11}$ and T-135/09, ${ }^{12}$ had the opportunity to rule again on the issue. While on the one hand the Court's decisions help to advance further on the path towards a more definite framework for the Commission's actions and for the rights of parties involved in raids, on the other hand a number of aspects remain unclear.

At the end of January 2009, the Commission conducted an inspection pursuant to Article 20 (4) of Regulation No 1/2003 at the premises of two leading power cable producers in Europe and worldwide, Prysmian in Milan and Nexans in Paris. The inspection decisions identified the scope of the dawn raid to be the "(potential) participation in anti-competitive agreements and/or concerted practices contrary to Article 81 CE ... in relation to the supply of electric cables and material associated with such supply, including, among others, high voltage underwater electric cables, and, in certain cases, high voltage underground electric cables ...". ${ }^{13}$

At Prysmian, inspectors examined the computers of five employees. During the second day of the dawn raids, they informed the company that the investigation would take longer than the three days initially planned. At that point, Prysmian's representatives expressed their availability to allow the inspectors to continue their job over the weekend or to seal the relevant premises and resume the following week. However, on the following day the inspectors decided to make a copy of the hard disks of three of the five Prysmian employees under investigation, with the aim of examining their contents at the Commission's offices in Brussels. Prysmian considered this method of inspections to be illegal, but the inspectors made clear that any opposition to the proposed procedure be considered as a breach of the company's duty to cooperate. Thus, Prysmian decided not to oppose and, in a declaration attached to the inspections' records, reserved the right to appeal this decision later in the procedure. The inspectors put the three copies in three separate sealed envelopes and examined their

\footnotetext{
${ }^{10}$ ERA conference 212DT12: The Conduct of Inspections for the Enforcement of EU Competition Law, held in Barcelona on 13 and 14 September 2012, at the Escuela Judicial de España. The event was cofinanced by the DG Competition of the European Commission.

${ }^{11}$ Case T-140/09, Prysmian S.p.A. and Prysmian Cavi e Sistemi Energia S.r.l. v European Commission, 14 November 2012 (not yet reported).

${ }^{12}$ Case T-135/09, Nexans France SAS and Nexans SA v European Commission, 14 November 2012 (not yet reported).

${ }^{13}$ See Prysmian judgment, $\S 3$, cit.; Nexans judgment, $\S 3$, cit.
} 
contents a month later, at the Commission's offices and in the presence of Prysmian's external lawyers.

At Nexans, inspectors interviewed one of the company's employees under investigation. On the third day of the raid, they discovered that a number of files, documents and e-mails, in their opinion relevant to the investigation, had been deleted from the hard disk of one of the employees they addressed. They then made copies of that hard drive and of a number of other documents; a copy was left to the company and two other copies were put in a sealed envelope and taken back to the Commission's offices in Brussels, where they were examined a month later in the presence of Nexans' external lawyers.

After the raids, both companies brought an action for annulment before the General Court on similar grounds. Among others, they argued that the inspection decision was imprecise in its delimitation of the products concerned, and that the high-voltage underwater cable sector was the only sector in relation to which the Commission had reasonable grounds for suspecting an infringement of the competition rules on the part of the applicants.

The General Court, in its preliminary observations, recalled that "the obligation on the Commission to specify the subject-matter and purpose of the inspection is a fundamental requirement in order both to show that the investigation to be carried out at the premises of the undertakings concerned is justified, enabling those undertakings to assess the scope of their duty to cooperate, and to safeguard their rights of defences". ${ }^{14}$ It is thus clear that, in case of antitrust investigations, a balancing exercise among conflicting interests must be carefully carried out. On the one hand, the Commission can count on the extensive powers granted by Regulation No 1/2003 to enforce the Union competition rules effectively; on the other, it, must safeguard the rights of defence of the parties concerned, and its action should not be arbitrary or disproportionate.

It follows from the above that the Commission must strictly respect the limits of its powers and comply with its obligations as defined by the relevant legislation and interpreted by the case law of the European Courts.

As for the obligation to define the subject-matter of the investigations, in the cases at stake the General Court found that the Commission's mandate contained "the essential information" to satisfy such obligation; the Court admitted that the "the grounds for that decision could have been less ambiguous", but finally considered that "they enabled the applicants to assess their duty to cooperate". 15

However, it must be noted that Prysmian and Nexans operate in very peculiar markets, in terms of both the characteristics of the products they produce and the markets' dynamics. As pointed out by the applicants, the expression "electric cables" could correspond to a wide variety of products, significantly different among themselves and certainly not attributable to the same sector of activities. It is difficult to dispute that "high-voltage submarine cables" and "cables for household electrical products" constitute two different and separate product markets, considering that not only the final usage, but also the entire production and installation processes are different.

\footnotetext{
${ }^{14}$ See Prysmian judgment, $\S 34$, cit.; Nexans judgment, $\S 39$, cit.

${ }^{15}$ See Prysmian judgment, $\S 47$, cit.; Nexans judgment, $\S 54$, cit.
} 
In addition, it must be recalled that the Commission started its investigations following a leniency application. Therefore, as required by the Commission's Notice on immunity from fines and reduction of fines in cartel cases, ${ }^{16}$ the leniency applicant, in its corporate statements, should have provided the Commission with " a detailed description of the alleged cartel arrangement, including for instance its aims, activities and functioning; the product or service concerned, the geographic scope, the duration of and the estimated market volumes affected by the alleged cartel (...)". It follows that, at the time it drafted its inspection decision, the Commission should have already gathered this set of information.

All this considered, one could argue that the ambiguous wording used in the Commission's decision does not appear to be justified by the circumstances of the cases. On the contrary, the Commission could have more clearly defined the subject-matter of the investigation, allowing the companies to assess properly the boundaries of their duty to cooperate.

After rejecting the first claim, the General Court reviewed whether the Commission had reasonable grounds for the purpose of justifying interference in the sphere of the applicants' private activity relating to all electric cables, or whether, as the parties claimed, those grounds were limited to the high-voltage submarine cables sector. The Court insisted on having a clear picture of the elements available to the Commission at the time of the inspections. After the hearing, the Court prescribed measures of organisation of procedure posing new questions to the Commission and ordering it to produce the information at its disposal which, in its view, justified the inspection decisions issued against Prysmian and Nexans. From the analysis of this information, the Court acknowledged that the Commission had reached the conclusion, before adopting its decision, that there were significant differences between high-, mediumand low-voltage power cables and that it did not demonstrate that it had reasonable grounds for ordering an inspection covering all electric cables and materials associated with those cables.

The matter is analysed in depth in the article "Dawn Raids of the European Commission: Limits to Document Seizure" by Yolanda Martínez Mata and Stefan Rating, part of this issue of ERA Forum. Here, only an additional consideration will be put forward. As described, the General Court in its judgments clearly recalled the importance, on the one hand, of the Commission's obligation to specify the subject-matter of the inspections, and, on the other, of its obligation to restrict its searches to the activities of the undertakings concerning which it has reasonable grounds to make an inspection. Both measures guarantee the respect of private parties' fundamental rights. What remains unclear is why the Court seems to adopt different standards in assessing whether the two obligations are satisfied, admitting a general and ambiguous approach for the first and proceeding to a substantially more severe analysis for the second.

The General Court was then asked to rule on the legality of the acts adopted by the inspectors during the dawn raids. In particular, the companies challenged the procedure of taking copy-images of the entire hard disks of their employees, with the aim

${ }^{16}$ Commission Notice on Immunity from fines and reduction of fines in cartel cases, OJ C 298, 08.12.2006, pp. 17-22. 
of reviewing their content at a later stage at the Commission's premises. The Court avoided entering into the debate and declared the claim inadmissible, stating that such acts are not separable from the decision under which the inspection was ordered, but only constitute implementing measures of it; therefore, the legality of those acts could only be examined in the context of an action challenging the final decision adopted by the Commission under Article 101 TFEU. This issue is very well presented in the above-mentioned article, and again, only a few supplementary considerations will be added here.

It is beyond dispute that, under Article 20(2) of Regulation No $1 / 2003,{ }^{17}$ the Commission has the power to examine books and other records related to the business and to take or obtain copies or extracts from them. In addition, as recalled by the Court, any inspection ordered under Article 20(4) ${ }^{18}$ of Regulation No 1/2003 implies a selection of documents to be examined and if necessary copied.

From the wording of the Regulation it is clear that the inspectors are entitled to proceed in two steps: the first being the examination of companies' documents and records, the second being the taking of copies of what is found to be relevant to the investigation. ${ }^{19}$ This is also the order referred to by the Court in its judgments. ${ }^{20}$

The companies claimed that the actions made by the inspectors reverse such order: they first took a copy of the entire hard-disks and only afterwards examined their content at the Commission's offices, deciding to keep what was found to be relevant for the investigations. As a matter of fact, the examination which normally should have taken place on-site and before the copy, was instead conducted off-site and after

\footnotetext{
${ }^{17}$ Article 20(2) of Regulation No 1/2003, cit., provides that:

The officials and other accompanying persons authorised by the Commission to conduct an inspection are empowered:
}

(a) to enter any premises, land and means of transport of undertakings and associations of undertakings;

(b) to examine the books and other records related to the business, irrespective of the medium on which they are stored;

(c) to take or obtain in any form copies of or extracts from such books or records;

(d) to seal any business premises and books or records for the period and to the extent necessary for the inspection;

(e) to ask any representative or member of staff of the undertaking or association of undertakings for explanations on facts or documents relating to the subject-matter and purpose of the inspection and to record the answers.

${ }^{18}$ Article 20(4) of Regulation No. 1/2003, cit., provides that:

(...) 4. Undertakings and associations of undertakings are required to submit to inspections ordered by decision of the Commission. The decision shall specify the subject matter and purpose of the inspection, appoint the date on which it is to begin and indicate the penalties provided for in Articles 23 and 24 and the right to have the decision reviewed by the Court of Justice. The Commission shall take such decisions after consulting the competition authority of the Member State in whose territory the inspection is to be conducted.

${ }^{19}$ The same wording, and thus the same order, was adopted in the previous Regulation defining the Commission's powers, see Regulation EEC Council: Regulation No 17: First Regulation implementing Articles 85 and 86 of the Treaty, Article 14, OJ 013, 21 February 1962, pp. 0204-0211.

${ }^{20}$ See, inter alia, Prysmian judgement, § 99: “Qualsiasi accertamento ordinato in forza dell'articolo 20, paragrafo 4, del regolamento 1/2003 implica una selezione di documenti da esaminare e, se del caso, da copiare. (...)”, cit.; Nexans judgment, § 121: “(...) any inspection ordered under Article 20(4) of Regulation No 1/2003 implies that a selection of documents will be examined and, depending on the case, copied, (...)", cit. 
the copies of different material, evidently not all relevant to the investigation, were taken.

It can be argued that in so doing, the inspectors acted beyond their powers. Neither the relevant legislation nor the case law of the EU Courts enable the Commission to examine and select the companies' documents and files of interest after the inspection has taken place. Nor can it be inferred that the dawn raids continue until the documents copied are examined at the Commission's premises in the presence of the companies' lawyers. To accept that would mean to concede that the inspections could last for weeks or even months. The latter solution could raise issues of discrimination among companies which undergo an on-site inspection lasting a few days and those which undergo an off-site one lasting weeks; the intrusion in the sphere of private activities would have different proportions in the two scenarios, and the same would be true for the company's duty to cooperate. Moreover, the proportionality of this way of proceeding should be assessed in the light of the general principles of EU law, and we can expect the EU Courts to be called upon to perform this exercise soon.

Meanwhile, it can be hardly argued that the recently published Revised Inspection Explanatory Note ${ }^{21}$ of the Commission contributes to bring clarity to the issue. On the one hand, at point 14 of its note, ${ }^{22}$ the Commission affirms that inspectors can secure the data still to be searched by placing it in a sealed envelope and invite the undertaking representatives to attend the opening of the envelope at the Commission premises and assist in the continued selection process. On the other hand, the Commission fails to provide any legal basis for what, as argued, seems to constitute an illegal extension of the inspectors' powers.

To conclude, the question of whether the Commission's procedure for the enforcement of EU competition law respects the fundamental rights of the parties and is compatible with the general principles of EU law has been on the table for some time. It acquired new importance, however, after the General Court's judgments of 14 November 2012.

Key issues concerning the Commission's powers during inspections were at stake. If on the one hand, the Court was very careful in examining whether the Commission had reasonable grounds to conduct an inspection concerning all of a company's activities, on the other it did not take the opportunity to dissipate doubts on other aspects of the Commission's actions during dawn raids. All in all, the judgments give further food for thought, and we can expect the dismissed challenges to be brought to Luxembourg again soon.

\footnotetext{
${ }^{21}$ European Commission, Explanatory note to an authorisation to conduct an inspection in execution of a Commission decision under Article 20(4) of Council Regulation No 1/2003, revised on 18/03/2013, available at: http://ec.europa.eu/competition/antitrust/legislation/explanatory_note.pdf.

${ }^{22}$ Point 14 of the Explanatory note, cit., provides that:

14. If the selection of the relevant documents for the investigation is not finished during the inspection on the undertaking's premises, the copy of the data still to be searched is secured by placing it in a sealed envelope and the undertaking will be provided with a duplicate. The Commission commits to return the sealed envelope to the undertaking or to invite the undertaking to attend the opening of the sealed envelope at the Commission premises and assist in the continued selection process.
} 


\section{References}

1. Bombois, T.: La protection des droit fondamentaux des entreprises en droit européen répressif de la concurrence. Lancier, Brussels (2012)

2. Bronckers, M., Vallery, A.: No longer presumed guilty? The impact of fundamental rights on certain dogmas of EU competition law. World Compet. 44(4), 535-570 (2011)

3. Editorial Comments, Towards a more judicial approach? EU antitrust fines under the scrutiny of fundamental rights. Common Mark. Law Rev. 48(5), 1405-1416 (2011) 